\title{
Civic education as an antidote to inequalities in political participation? New evidence from English secondary education
}

\section{James Weinberg ${ }^{1}$}

Accepted: 18 June 2021 / Published online: 3 July 2021

(c) The Author(s), under exclusive licence to Springer Nature Limited 2021, corrected publication (2021)

\begin{abstract}
Entrenched inequalities in political participation have made the questions of who participates and when, why, or how some of the most frequently asked and researched in political science. Building on existing comparative research, this article focuses on civic education in English secondary schools and, in particular, the ability of related interventions to close participation gaps normally seen by sex, ethnicity and socio-economic status. Analysing original survey data collected from more than 350 students in 17 maintained secondary schools located in six regions of England, this article evaluates the impact of four types of civic education (curricula lessons; open classroom climate; participatory activities; and political contact) on three participatory outcomes (expressive political behaviours; voting intentions; and anticipated high-intensity participation). Descriptive and inferential analyses suggest (a) cumulative quantities of civic education are positively associated with youth political participation; (b) open classroom climate may close known inequalities in young people's expressive and electoral participation whilst political contact with politicians and political institutions may widen those inequalities; and (c) civic education may currently accelerate inequalities in young people's political ambition. These findings raise important and immediate challenges for policy-makers who are concerned with improving young people's civic engagement in England and elsewhere.
\end{abstract}

Keywords Political participation · Inequality $\cdot$ Civic education $\cdot$ Political contact Voting $\cdot$ Political ambition

James Weinberg

james.weinberg@sheffield.ac.uk

1 Lecturer in Political Behaviour, Department of Politics and International Relations, University of Sheffield, Elmfield Building, Northumberland Road, Sheffield S10 2TU, UK 


\section{Introduction}

By participating in politics, citizens can make their interests known and pressure representatives or governing authorities to give them equal consideration (Dahl, 1989; Warren, 2002). Widespread political participation thus undergirds the normative ideal-type of an inclusive democratic society, but it also correlates positively with practical indicators of effective and well-functioning national governments (notable examples being Norway, New Zealand, Canada and Denmark; see Dalton 2017). In reality, however, the opportunities to participate in politics are not evenly distributed throughout populations (for overviews, see Teorell et al. 2007; Plutzer 2018). For example, women are less likely to stand for political office than men, but they are more likely to participate in politics through informal or expressive behaviours (see Burns et al. 2001; Marien et al. 2010). Younger cohorts of citizens are generally less represented at the ballot box or on the ballot paper, but do engage much more online and beyond party politics (e.g. Sloam and Henn 2018). In turn, ethnic minority citizens are less likely to register to vote, turn out to vote, or to be descriptively represented in parliaments and legislatures in the US and across both Europe and the anglosphere (e.g. Bird et al. 2011; Heath et al. 2013). ${ }^{1}$ A growing repertoire of non-institutional or 'expressive' political behaviours also appears to entrench the formal participation gap seen between groups with low and high socioeconomic status (SES) (see Dalton 2017; OECD 2017, p. 166).

It is in this context that academics as well as practitioners have sought to interrogate the dynamics of participatory inequalities and find ways to redress them. One avenue of investigation has centred upon civic education (elsewhere referred to as 'citizenship', 'political' or 'democratic' education). Civic education is used here as a holistic term that encompasses institutional and non-institutional mechanisms concerned with enhancing learners' abilities to handle evidence, articulate and substantiate arguments, engage critically with the social and political world, and understand key democratic concepts, issues and processes as well as their membership of local, national and global communities (for comparative discussions, see Davies et al. 2019). Extant research suggests that civic education may increase young people's social capital, political knowledge and even political participation (Delli Carpini and Keeter 1996; Campbell 2006; Campbell and Niemi 2015; for a longitudinal review, see Knowles et al. 2018). The importance of civic education in this respect can also be seen in policy documents such as the Council of Europe's 2018 Reference Framework of Competences for Democratic Culture (RFCDC) (Barrett 2020).

Crucially, a nascent yet expanding body of research also suggests that civic education might be able to overcome inequalities in political participation (Campbell 2008; Hooghe and Dassonneville 2013; Castillo et al. 2015; Neundorf et al. 2016;

\footnotetext{
1 The phrase 'ethnic minority' is used to reflect the current approach to writing about ethnicity that is used by the UK Government's Race Disparity Unit. The author acknowledges that binary distinctions, including other frequently used terms like BME and BAME, are woefully inadequate. Future research should seek to disaggregate these terms in relation to citizenship education by acquiring sufficient sample sizes to better focus on understanding disparities and outcomes for specific ethnic groups.
} 
Hoskins et al. 2017). To the extent that schooling is available to everyone in most contemporary states, school-based civic education can create or maintain political equality by developing young people's democratic knowledge, skills, and attitudes. In doing so, civic education may close the participatory gaps outlined above, which have been held up as reflective of both a 'civic opportunity gap' (see Clay and Rubin 2020) and a 'civic empowerment gap' (see Levinson 2013). However, the precise mechanisms by which education per se, and civic education in particular, can improve political participation and overcome such inequalities remain rather opaque. For this reason, Campbell and Niemi (2015, p. 508) argue:

Just as plentiful data has ensured a voluminous literature on math and reading, so too would our understanding of what makes for effective civic education expand with more and better data.

This article takes an incremental step forward in addressing this gap by analysing new data gathered from secondary school students in England. Focusing on three types of civic education - formal curricula 'citizenship education', political contact, and participatory learning — and one style of delivery — open classroom climatethis article assesses the impact of school-based provision on young people's current likelihood of engaging in a range of expressive political behaviours and their future likelihood of engaging in a range of low and high intensity electoral behaviours. The contribution of the paper is twofold. On one hand, it provides a much-needed update to existing evidence on links between school-based civic education and young people's politics in England, which has been largely neglected since the end of the Citizenship Education Longitudinal Study (CELS) in 2010 as well as England's withdrawal from the International Civic and Citizenship Study (ICCS) after 2009 and the end of subject specific reports on curriculum citizenship education by Her Majesty's Inspectorate, Ofsted, in 2013. On the other hand, this article builds substantively on existing work in political science and education by (a) replicating research on well-known aspects of civic education (i.e. curricula provision, participatory activities, and open classroom climate), (b) providing original data on one previously under-researched aspect (i.e. political contact), and (c) evaluating the 'compensatory' effects of all four upon three 'tiers' of participation. These lines of inquiry and the findings that arise from them raise important questions for academics studying the relationship between education and politics as well as policy-makers, school leaderships and interested third sector stakeholders who seek to eradicate political inequality.

\section{Civic education and political participation}

This article focuses specifically on four aspects of civic education: formal compulsory learning, participatory activities, political contact, and open classroom climate (OCC). For the benefit of the uninitiated, these may be summarised as follows. Firstly, formal learning manifests in curriculum-based lessons or opportunities that occur regularly as part of young people's ordinary education. These lessons tend to 
exhibit considerable comparative variation in line with the symbolic and ideological needs or preferences of national governments (e.g. Weinberg 2019). Second, participatory learning refers to forms of non-mandatory provision within schools such as student councils, debating societies or mock elections, all of which tend to be more elusive and dependent on school ethos than statutory curricula lessons (for analysis, see Keating and Janmaat 2016). Thirdly, political contact-previously under-developed as a focus of civic education research—captures those interactive moments between young people and political actors or institutions that may be facilitated through the education system. Finally, OCC refers to the learning culture in a classroom with a particular focus on the extent to which young people are encouraged to debate, form and express individual opinions, and introduce issues for class discussion (see Martens and Gainous 2013; Quintelier and Hooghe 2013).

In their systematic review of more than 100 related peer-reviewed articles, Knowles et al. (2018, p. 12) identify clear and replicable relationships between civic education and dependent variables such as 'civic knowledge, expected participation and students' attitudes towards political institutions and towards rights for immigrants and political rights for women.' Drawing on data collected from young people in 24 countries, the 2016 IEA International Civic and Citizenship Education Study (ICCS; Schulz et al. 2016, p. 209) drew similar conclusions:

[the] promotion of civic and citizenship education, in both formal and informal ways, should be considered as an essential means of helping young people become more conscious of their political roles and the importance of being participating citizens.

The contemporary evidence base in England (the locale of this article) is somewhat more anaemic. The most robust and detailed body of evidence on English civic education was collected by the CELS, which was commissioned by the Department for Children, Schools and Families (DCSF) to investigate the impact of compulsory 'citizenship' education on school students between 2002 (when it was introduced) and 2010. The final report noted:

[T] he CELS cohort [i.e. a group of pupils who were tracked and regularly surveyed during their period of full time education] was more likely to have positive attitudes and intentions towards civic and political participation (both in the present and in the future) if they had high levels of 'received citizenship' (i.e. if they reported having received 'a lot' of citizenship education). (Keating et al. 2010, p. vi)

The general consensus of a dense comparative research base is, then, that the amount of civic education received in adolescence may stimulate higher levels of political participation (see also Whiteley 2014; Keating and Janmaat 2016). Yet as Donbavand and Hoskins (2021) rightly point out, these claims are largely reliant on observational data. Their systematic review of the field uncovered just 25 studies, mostly in the US and UK, that used controlled trials to isolate casual relationships. These studies do, however, reaffirm strong links between otherwise well-studied aspects of civic education (such as participatory approaches, teacher training, 
and whole school ethos) and young people's political engagement. Donbavand and Hoskins (2021, p. 15) conclude: 'the general picture is one which appears to broadly confirm the existing knowledge in the field'. These findings are expected to replicate for all students (i.e. young men and women, white students and ethnic minority students, and those with high and low SES) in the current study of contemporary civic education in English secondary schools.

H1 The more civic education young people receive (of any type), the more likely they will be to participate in politics (formally or informally).

The primary concern of this article, however, is the extent to which the positive effects of civic education on young people's political participation (now and in the future) might mitigate inequalities in formal and informal participation. So-called 'compensatory effects' have already been researched in a number of countries. For example, Campbell and Niemi (2015) demonstrate disproportionate effects of highstakes civic education exams on the political knowledge of immigrant and Latino students in the US. Similarly, Campbell (2008) shows that 'exposure to an open classroom climate at school can partially compensate for the disadvantages faced by young people with low socioeconomic status' when it comes to anticipated voter turnout. Again using US data, Martens and Gainous 2013 find that OCC impacts low SES students' intent to vote (though to a smaller extent than Campbell), whilst Neundorf et al. (2016) use Belgian and US data to show compensation effects for students' interest in politics but not actual levels of political participation.

More recently, Sloam et al. (2021, pp. 310-313) utilise data from eight waves of the European Social Survey (including young people from England) to demonstrate that being in higher education - over and above educational attainment per se-has a much larger impact on the political interest, engagement and efficacy of students from low-income backgrounds than it does on their peers from high-income backgrounds. These findings point to the important political socialisation provided by educational establishments such as universities. Whilst this is an important and positive finding, schools remain a more obvious and apposite site for related research into the compensation thesis. Very simply, secondary education is a universal right for all children, whilst higher education remains a selective experience (in 2020, entry rates for university places in England ranged from $32.6 \%$ of White British students to $71.7 \%$ of Chinese British students; see UK Government 2021). For civic education to truly act as a levelling spirit for democratic participation, delivery needs to occur in sites that are ostensibly, or legally at the very least, accessible to all.

In England, the Youth Citizenship Commission (YCC)—set up in 2009 by the UK Government in light of growing concerns about youth democratic participation-found that 'working-class youngsters' in English schools were less likely to vote, volunteer, know about how decisions are made in politics, or feel any responsibility for improvements to their local area (Tonge et al. 2012, pp. 587-594). Yet whilst these concerns about political inequalities among school-aged children have now been prominent for a number of years, the only study of the compensation 
effect in English schools to date [known to the author] was conducted on CELS data (now over a decade old) by Hoskins et al. (2017). The authors' retrospective analysis showed that formal citizenship education in school was effective in reducing inequalities in voting intentions among 15-16 year olds, but access to in-school political activities, such as debating clubs, was also negatively structured by students' social backgrounds.

Though incredibly informative, the aforementioned studies of school-based civic education suffer from a number of limitations. Firstly, doubts exist about the replicability of current empirical findings. In a study of Swedish panel data as well as ICCS data on 28 countries, Persson (2015) was unable to find consistent compensatory effects for civic education on political participation. There is, then, a need for more detailed and repeated investigation of this issue. Second, research into the compensation thesis focuses overwhelmingly on formal participation (and especially young people's voting intentions) without considering the potential impact of civic education on other high-intensity modes of participation (such as running for office) or a range of informal, expressive modes of participation (such as political consumerism, demonstrations and online activism). Third, extant research similarly tends to focus on one or two aspects of civic education (such as either OCC or curricula provision) without simultaneously considering a full framework of school-based activities that might influence political behaviours and attitudes. This article seeks to address each of these gaps.

\section{Compensation effect: hypotheses}

In taking the evidence and arguments provided above and formulating empirical expectations, it is anticipated that curricula citizenship education will have consistent positive effects on young people's political participation. Moreover, as a feature of the English National Curriculum, formal citizenship education should write out inequalities in access to other types of provision that rely on opt-in mechanisms or self-selection. In doing so, it is expected to close the participation gap normally seen by gender, ethnicity and SES. More likely to take the form of transmission-based, knowledge-oriented education about political systems and institutions as opposed to active or dialogic education about political issues (see DfE 2013), curricula provision is also expected to share stronger associations with formal participatory acts such as voting rather than informal political acts that require a heightened level of skills-based activity or non-institutional direction (see below).

H2 Curricula citizenship education will have a stronger positive impact on the participatory intentions of under-represented groups than over-represented groups.

In contrast, participatory activities are expected to share stronger associations with young people's expressive political participation and to close inequalities therein. Put another way, these types of civic education are more likely to benefit students who do not already witness political participation or ambition among 
friends and family members or engage in conversations about social, political or controversial issues at home (e.g. Delli Carpini and Keeter 1996; Neundorf and Smets 2017). Whilst political parties may be able to mobilise particular ethnic minority communities or low SES groups on election day to facilitate turnout, expressive forms of participation rely much more on individual social and political capital that may be cultivated through participatory learning in school.

H3 Participatory civic education will have a stronger positive impact on the participatory intentions of under-represented groups than over-represented groups.

Across countries, contexts and timeframes, OCC shares the most consistent positive associations with young people's political attitudes and behaviours (e.g. in Latin America: see Trevino et al. 2016; Garcia-Cabrero et al. 2017; in western Europe: see Torney-Purta and Barber 2005; Knowles and McCafferty-Wright 2015; in Thailand and Hong Kong: Kennedy 2012; and in the United States: Campbell 2008; Zhang et al. 2012). As Martens and Gainous (2013, p. 18) put it, 'the unmistakable conclusion to be drawn from our research is that fostering an open classroom climate is the surest way to improve the democratic capacity of America's youth.' In line with this evidence base, OCC is expected to share the strongest associations with young people's current and anticipated political participation (both electoral and expressive). Compensation effects evidenced elsewhere (largely in the US, see previous section) are also expected to replicate in this study with a particular benefit seen among low SES students.

H4 Open classroom climate will have a stronger positive impact on the participatory intentions of under-represented groups than over-represented groups.

Although it does not feature in the existing research base on civic education, political contact is a cornerstone of representative democracy that can catalyse a range of positive participatory effects such as improving citizens' political efficacy (Tedesco 2006), the likelihood of their electoral turnout (Kleinnijenhuis et al. 2001), and even their voluntary re-engagement with representatives (Soo et al. 2020). It is anticipated that these effects will also manifest amongst young people who are visited by politicians in school or who have the opportunity to attend political institutions through school trips. In turn, it is expected that the compensation effects of political contact will be largest for high-intensity modes of formal participation such as standing for political office. Existing research has already shown, for example, that women and ethnic minority groups are more politically active when they are represented by women or ethnic minority politicians, and that such effects are magnified for young women exposed to new female candidates (Uhlaner and Scola 2016; Wolbrecht and Campbell 2007).

H5 Political contact will have a stronger positive impact on the participatory intentions of under-represented groups than over-represented groups. 


\section{Methods}

\section{Data collection}

In late February 2020, electronic surveys were administered to students in maintained [state-funded] secondary schools in England (including those with academy status). Invitations to participate were communicated to 15,000 teachers by emails from the UK Parliament's Education Service (PES) as well third sector education charities and social enterprises. Teachers were invited to administer an anonymous electronic survey to their students in one or more age groups and to encourage colleagues of all disciplines to do the same with other classes and age groups in their school. This exercise was entirely voluntary. Teachers were provided with detailed participant information sheets that they were asked to share with students and/or parents before administering the surveys. This research was ethically approved in advance by the University of Sheffield's Department of Politics and International Relations (Reference Number 031460).

\section{Participants}

Due to the onset of the 2019-20 coronavirus pandemic, data collection only lasted two weeks before schools in England closed for an indefinite period. In that time, 399 secondary school students completed an online survey about learning politics in school. Attention filters were used to control for completion quality, leaving a final $N$ of 367 . The sample was predominantly female (60\%), had an average age of $14(\mathrm{SD}=1.95$, minimum $=11$, maximum $=19)$, and $57 \%$ identified as white. Participants attended 17 different maintained secondary schools spread around six regions of England. They reported very different academic aspirations: a majority $(63 \%)$ of participants believed that they would go on to get a university-level qualification or higher, but $14 \%$ did not see themselves achieving anything beyond basic school-level qualifications (GCSEs).

Although the sample is diverse across a number of key demographic, socioeconomic and geographical variables, it is important to note that it is based on a non-probability sampling procedure. This was a necessary consequence of the difficulties involved in accessing school students as a research population, which must be done indirectly through advocates and ethically approved intermediaries. Future projects with sufficient funding and institutional partnerships (i.e. with the Department for Education) should seek to access a simple random or systematic sample of the entire student population. The present sample is sufficient, however, for field-testing key hypotheses about civic education and political inequality that can inform larger replication studies. To improve the accuracy and generalisability of the results reported in the rest of this article, post-stratification weights for age, gender and ethnicity are applied to the data to bring it in line with published statistics on the national population of students in maintained 
secondary education at the time of data collection (DfE 2019). Individual weights range from 0.217 to 2.713 with a general design effect of 1.313 .

\section{Measures}

\section{Dependent variables: political participation}

Expressive participation is measured here as a scaled variable based on students' self-reported likelihood of engaging in seven related behaviours (see Table 1). Students responded to each item using a five-point Likert scale running from 'Very Unlikely' to 'Very Likely' to engage in each specified behaviour. Participants' scores were then averaged across all seven items to produce one aggregated variable. The same Likert scale was used to measure students' anticipated likelihood of voting in a national election when aged 18 or older as well as their likelihood of joining a political party, helping to campaign for a politician, or standing for election themselves. Scores for these latter three behaviours are aggregated into an average likelihood for future high-intensity participation.

Table 1 also reports frequencies, chi-square associations and correlation coefficients for each participatory behaviour by gender, ethnicity and SES. The data indicate that (a) young people in England are not particularly likely to participate in most political behaviours and (b) testify to inequalities in political participation documented in adult populations. For example, young women are more likely to engage in expressive modes of participation, but the differences between young men and women disappear when it comes to high-intensity forms of participation such as campaigning for a political party or standing for office. Equally, white students and high-SES students are also more likely than their ethnic minority or low SES peers to participate in a range of expressive political behaviours; more likely to anticipate voting in the future; and more likely to anticipate joining a political party or campaigning in an election.

\section{Independent variables: civic education}

Students were asked to self-report how frequently they had experienced a range of civic education activities over the previous year of schooling. Responding on a seven-point Likert scale of 'Never' to 'Every Day', students indicated how often they (a) received whole lessons dedicated to politics or citizenship education (formal curricula provision), (b) had the chance to vote on topical issues in class, elect student representatives, or contribute to decisions about how the school was run (participatory learning), or (c) were visited by politicians in person or digitally, or went on school trips to political institutions such as the UK Parliament or local council offices (political contact). Drawing on measures of OCC fielded by ICCS, students also reported how often they were encouraged in daily lessons to discuss social and political issues, make up their own mind on said issues and express those opinions in class, or to consider multiple sides of social and political arguments. Responses to these items were gathered using a four-point Likert scale of 'Never' to 'Often'. 


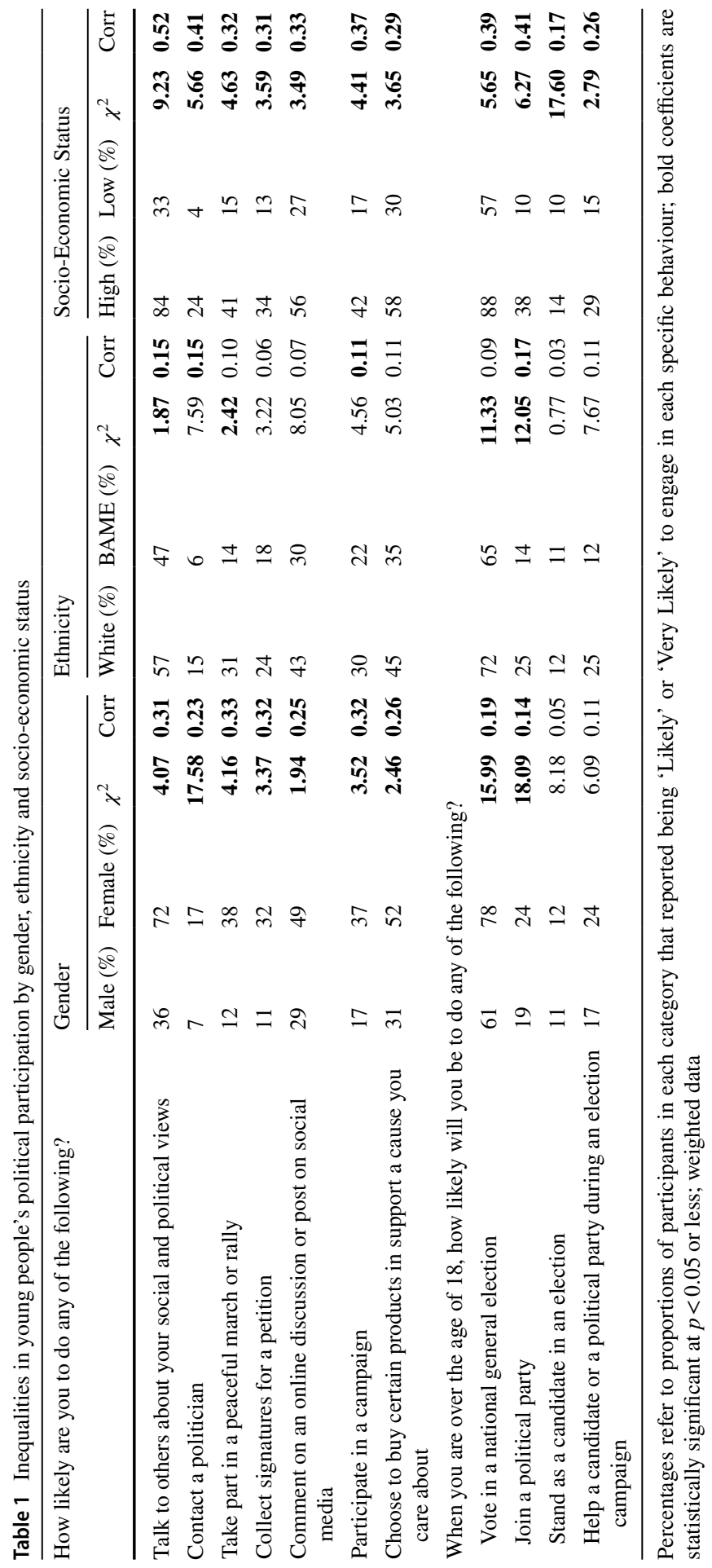

承 


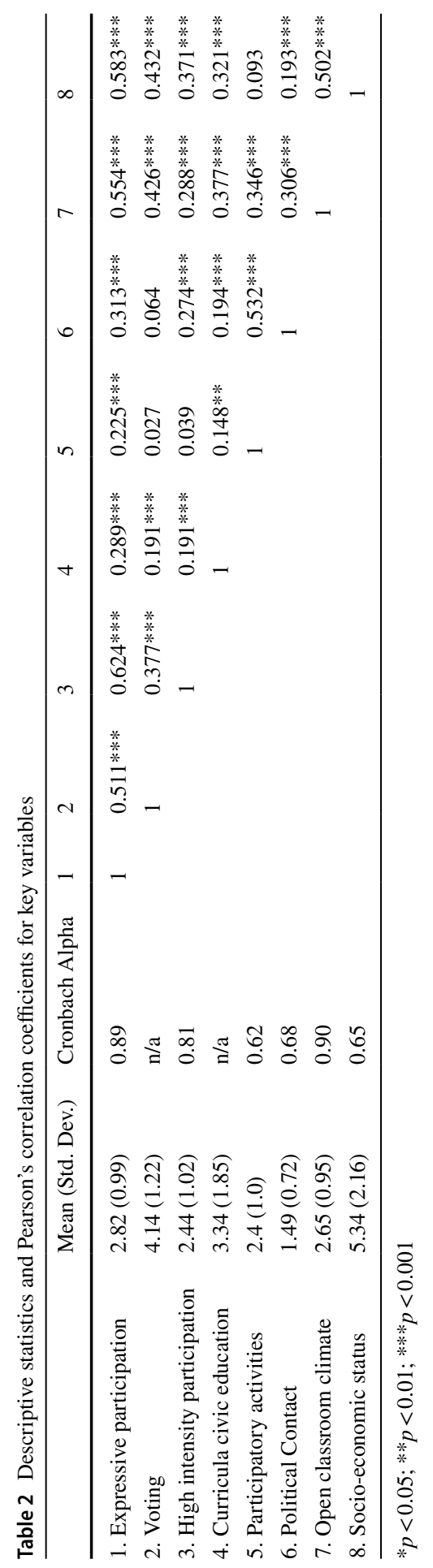


Students' scores for participatory activities, political contact and OCC were calculated as their average response to the items outlined above. Descriptive statistics, Cronbach alpha coefficients, and inter-item/scale correlations for these measures can be found in Table 2 .

\section{Independent variables: socio-economic status (SES) and school composition}

As noted earlier, SES is considered to be a powerful predictor of inequalities in political participation. This article follows the example of existing research with school children by measuring SES using a home environment index (see Gainous and Martens 2012). Put simply, SES is measured as a composite variable based upon (a) the number of books in a students' home (measured on a five-point Likert scale) and (b) students' self-reported level of political socialisation with family members (also scored on a five-point Likert scale). Participants in this study were drawn from very different SES backgrounds. For example, $41 \%$ had fewer than 25 books in their household (and 18\% had fewer than 10), whilst 20\% self-reported more than 200. Some $30 \%$ of participants had 'never or hardly ever' spoken about 'social or political issues' at home with family or friends, but $20 \%$ did so on a daily or almost daily basis.

Knowles et al. (2018, p. 21) argue that 'future research could consider the nature of classroom composition.' Over and above students' individual attributes, it is entirely possible that classrooms or schools with particularly homogeneous or heterogenous student populations are more or less conducive to effective civic education. To account for school composition in subsequent inferential analyses, a binary variable is devised here based on the percentage of students claiming free school meals (FSM) in each participant's school. At the time of data collection, children in England were eligible for FSM if they came from a household that (a) had an annual gross income of $£ 16,190$ or less, or (b) was in receipt of income-related support, tax credits or Universal Credit. Where more than one in five students (i.e. $20 \%$ of the school population) claimed FSM, participants' schools are classified as having high levels of socio-economic deprivation. In total, 131 participants attended seven schools with low percentages of FSM (i.e. $<20 \%$ of the student population) and 232 attended ten schools with high percentages of FSM.

\section{Analyses}

The analysis in this article proceeds in three sections. The first presents descriptive statistics on students' self-reported levels of received civic education across individual items. These data provide a snapshot of the 'state-of-play' in civic education provision amongst the present sample. The second section amalgamates students' average scores for curricula civic education lessons, participatory activities, political contact and OCC (as per Table 1) into a single sum score, which is then rescaled $0-1$ for the sample population and split into three near equally populated categories of 'weakest provision' (scores up to half a standard deviation below the mean, $N=112$ ), 'moderate provision' (scores one standard deviation around the mean, 
$N=108$ ), and 'strongest provision' (scores above half a standard deviation over the mean, $N=115$ ). This composite variable is used to assess the relationship between students' cumulative quantity of received civic education and their participatory outcomes by sex, ethnicity and SES (as per Hypothesis 1). These comparisons are supported in-text by the results of multiple factor (two-way) ANOVAs. The third and final section of the analysis tests hypotheses 2-5 using weighted least squares multiple regressions. Cluster robust standard errors are also used to account for heteroskedacity across groups of students located at different school sites. These models are used to assess the differential effects of each aspect of civic education upon (a) expressive participation, (b) anticipated voter turnout, and (c) political ambition (as the apogee of high-intensity participation). These three analyses are each run using subsets of the data so that the strength of pathway coefficients for different sub-samples (high/low SES, men/women, ethnic minority/white students) can be compared whilst controlling for potential differences in access to provision, socio-economic and demographic characteristics, and school composition (see Online Appendix).

\section{Results}

This article explores original data collected from a nationally diverse sample of English secondary school students in order to ascertain the potential compensation effects of civic education upon inequalities in current and future political participation.

\section{Access to civic education}

Ten years after the CELS stopped tracking statutory citizenship education in English schools, it seems that civic education remains a peripheral feature of young people's secondary education. Formally, just $24 \%$ of students reported weekly lessons in politics or citizenship. The same proportion had never received such a lesson. Whilst shocking, these figures complement official statistics. For example, the 2019 School Workforce Census (DfE 2020) found that out of 2876 English secondary schools, only 456 reported having a trained citizenship education teacher. Where schools did report teaching curriculum citizenship education, it accounted for just $1.9 \%$ of teaching hours. Returning to the present study, participatory activities appear equally scarce in English schools. Only $18 \%$ of students had voted on topical issues at school once a fortnight or more in the last year; $20 \%$ had never voted for a student representative; and $32 \%$ had never been given the chance to participate in decisionmaking about how their school is run. Political contact is even more marginal as a form of civic education in English maintained schools. $71 \%$ and $69 \%$ of students respectively had never interacted with a politician at school or visited a political institution on a school trip.

Weighted independent samples $t$-tests also suggest that SES and school composition may structure students' access to civic education (Figs. 1 and 2). In particular, students with low SES reported lower levels of formal curricula provision 


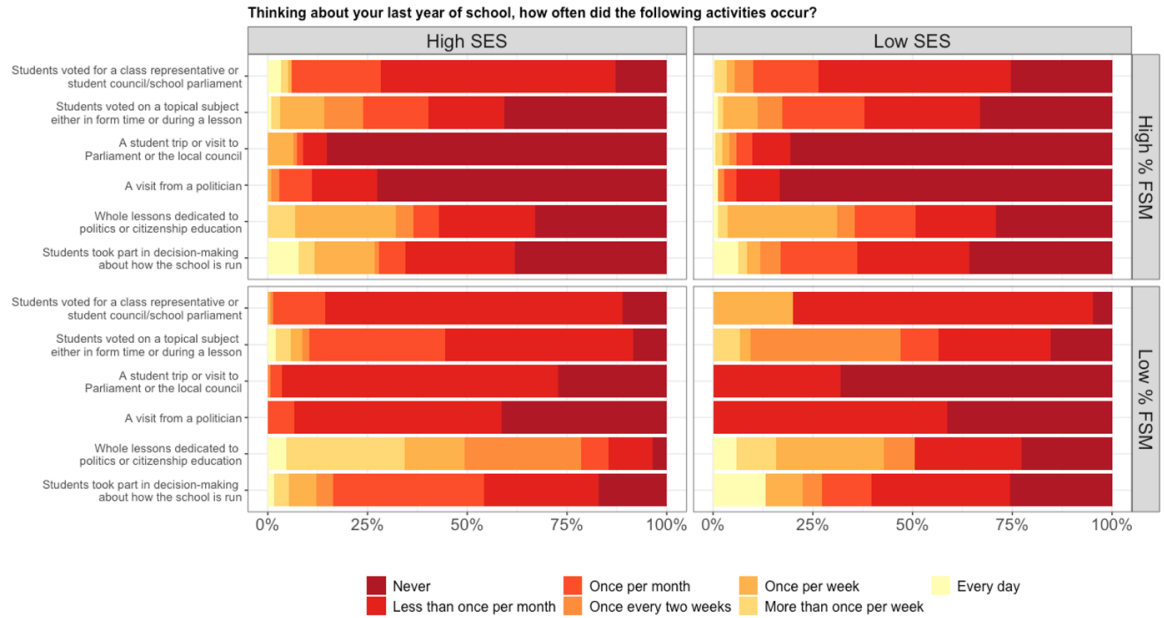

Fig. 1 Self-reported access to civic education in English secondary schools by students' socio-economic status and school composition

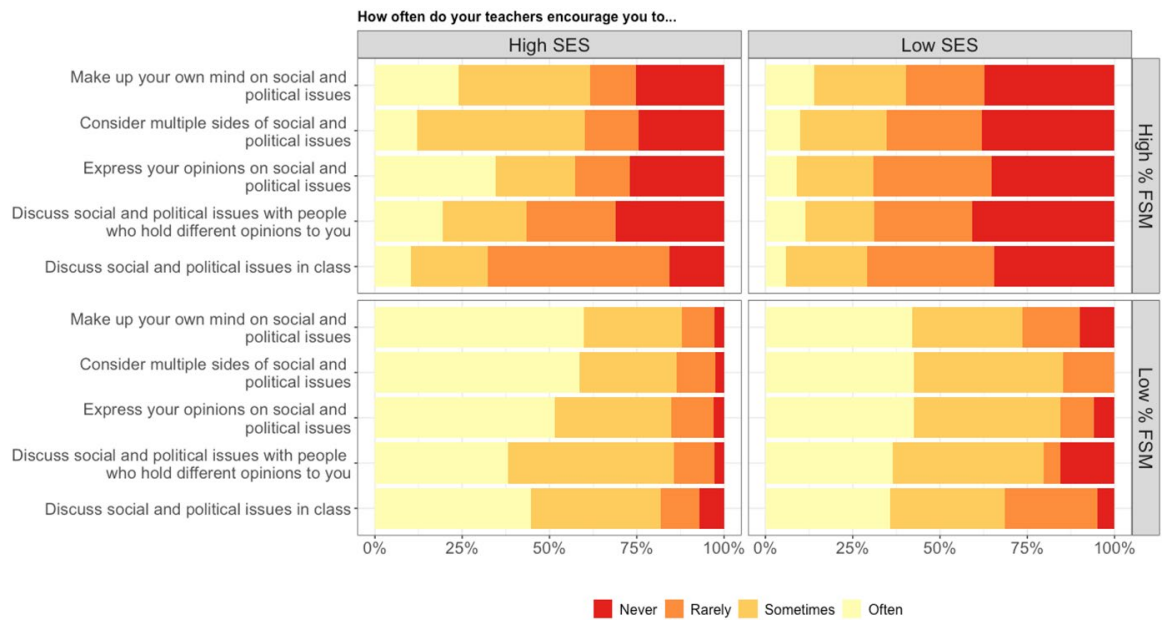

Fig. 2 Self-reported access to an open classroom climate in English secondary schools by students' socio-economic status and school composition

$(t(341)=-3.991, p<0.05)$, less political contact $(t(312)=-2.535, p<0.05)$, and lower perceived levels of OCC $(t(335)=-8.828, p<0.001)$. With the exception of formal provision, these results mirror comparative findings in countries such as Germany, Belgium and the Netherlands (Deimel et al. 2020). Likewise, participants studying in schools with a high percentage of FSM claimants reported less frequent lessons on politics and citizenship $(t(338)=-7.877, p<0.001)$, less political contact $(t(323)=-2.494, p<0.05)$ and lower perceived levels of OCC $(t(306)=-13.585$, $p<0.001)$. These differences are starkest at the intersections of these variables. For 

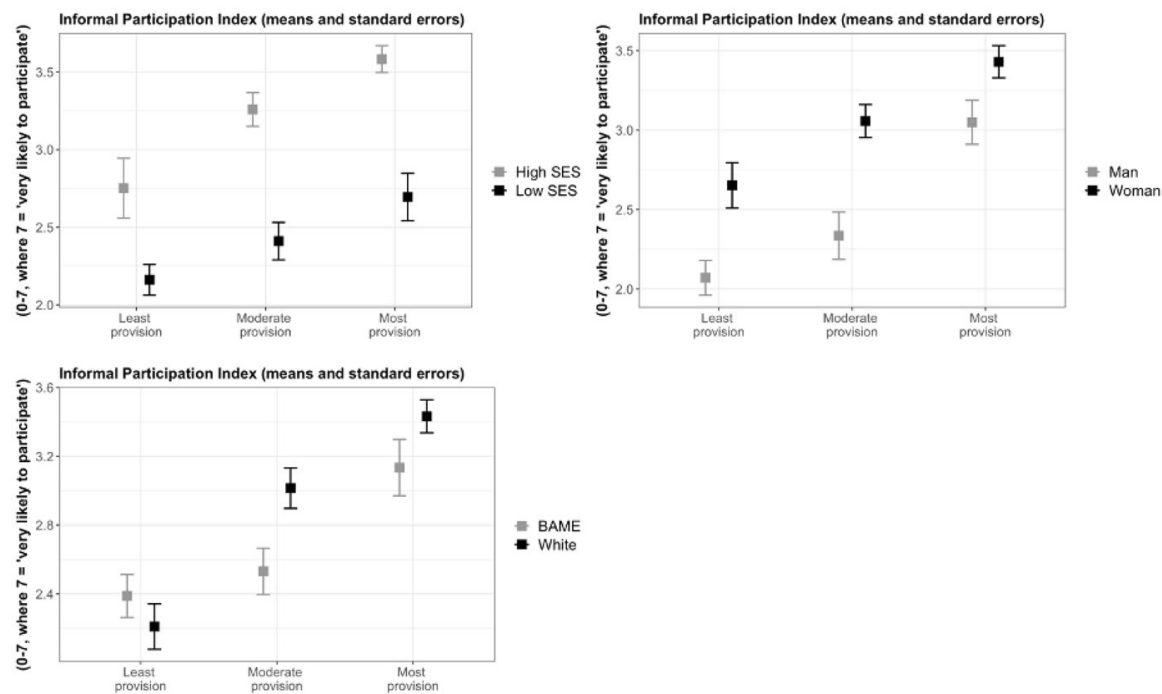

Fig. 3 Civic education provision and young people's informal political participation

example, 35\% of high SES students in schools with a low percentage of FSM claimants reported whole lessons on politics more than once a week. This is compared to just $4 \%$ of low SES students in schools with a high percentage of FSM claimants. Likewise, $60 \%$ of high SES students in schools with a low percentage of FSM claimants reported that they were 'often' encouraged to make up their own minds about social and political opportunities. Just $14 \%$ of low SES students in schools with a high percentage of FSM claimants said the same.

\section{The impact of civic education: cumulative quantity}

Figures 3, 4, 5 illustrate the average likelihood of students' participation in politics via non-institutionalised expressive behaviours, future voting intentions, and future high-intensity participation. In each case, these scores are compared by gender, ethnicity and SES as well as the relative overall quantity of civic education (of all types) received by students at school in the last year. In the first instance, the quantity of civic education experienced by participants appears to have a powerful socialising effect on average levels of expressive political participation (see Fig. 3; H1 supported), regardless of whether students are divided by SES $(F(2,292)=33.55$, $p<0.001)$, sex $(F(2,292)=30.58, p<0.001)$, or ethnicity $(F(2,292)=29.19$, $p<0.001)$. The data do not reveal any significant interaction effects between these variables, which would suggest that the quantity of civic education provision received by students explains a similar amount of variance in expressive participation among white and ethnic minority students, young men and women, and high/ low SES groups.

The main effects of civic education on participants' voting intentions (Fig. 4) are also statistically significant among SES groups $(F(2,295)=5.81, p<0.01)$, 

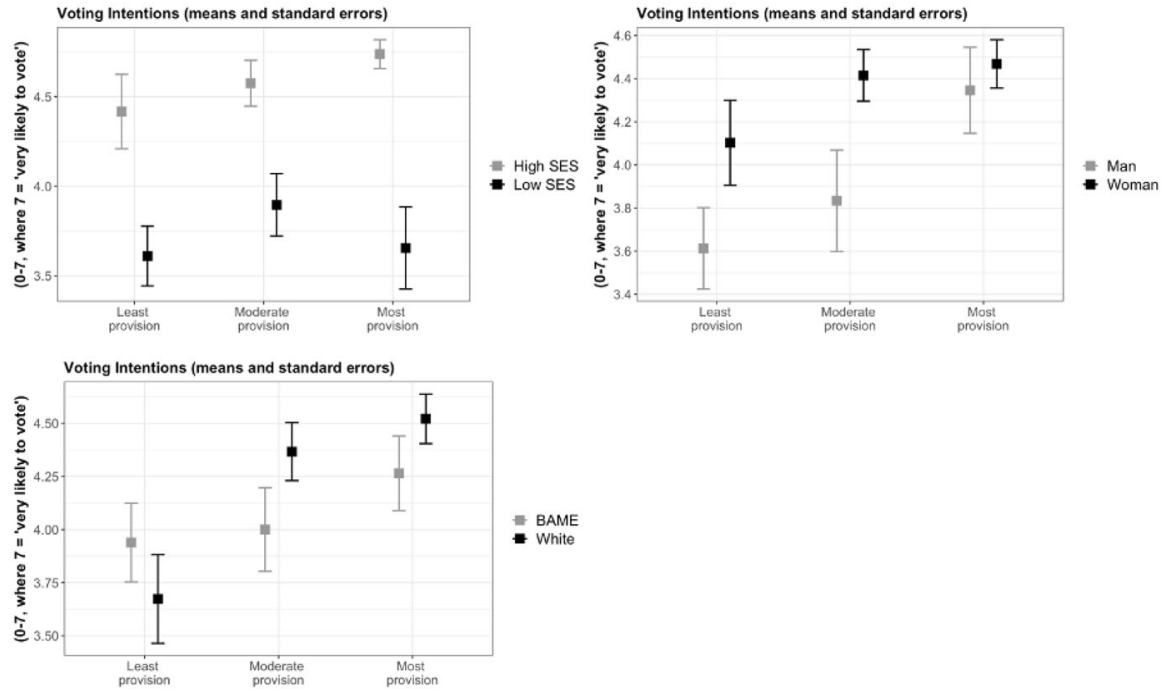

Fig. 4 Civic education provision and young people's voting intentions
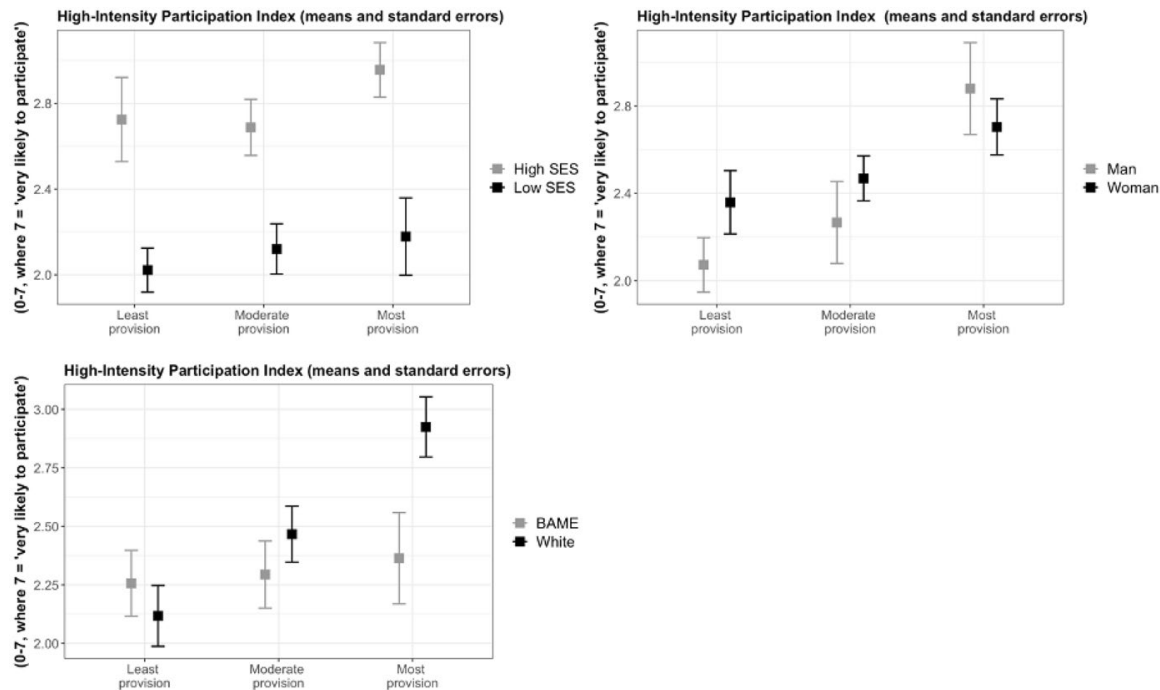

Fig. 5 Civic education provision and young people's anticipated high-intensity participation in politics

across sexes $(F(2,295)=5.15, p<0.01)$, and among different ethnicities $(F(2$, $295)=5.12, p<0.01)$. These results provide compelling evidence of a generalised link between young people's anticipated turnout in elections and the ситиlative amount of civic education they receive in school (H1 supported). These associations are, however, much smaller than those demonstrated between 


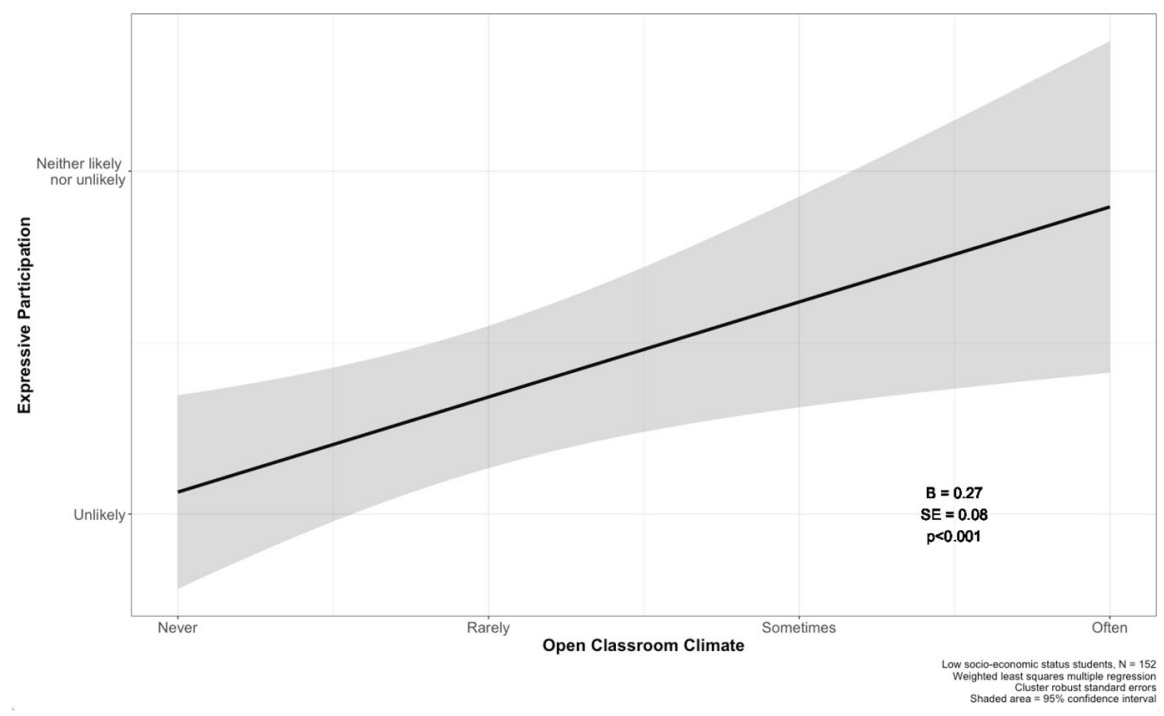

Fig. 6 Predicted effects of open classroom climate on the expressive participation of students with low socio-economic status (original scales)

civic education and participants' current expressive participation in politics (see above). Once again, none of the interactions tested here reach statistical significance.

Finally, received levels of civic education map positively onto students' likelihood of high-intensity participation in politics in the future (Fig. 5). These effects are statistically significant regardless of participants' $\operatorname{SES}(F(2,291)=6.52, p<0.01)$ or $\operatorname{sex}(F(2,291)=6.04, p<0.01)$. As such, schools and policy-makers may be able to encourage young people to join political parties, campaign in elections, or stand for office by providing more civic education in mainstream education. It is worth noting that these effects are, once again, weaker than the relationship found between cumulative civic education and participants' expressive participation. At the same time, these analyses reveal a marginal yet notable interaction effect between quantities of civic education provision and ethnicity $(F(1,291)=2.33, p<0.09)$. Put simply, this would suggest that civic education may significantly improve students' anticipated high-intensity participation, but only when those students also self-identify as white.

\section{The impact of civic education: aspects of provision}

This article now interrogates whether or not individual aspects of civic education (curricula lessons, participatory activities, OCC, and political contact) may drive the effects reported above and whether or not they can compensate for known participatory inequalities. The following findings are derived from a series of weighted multiple regressions that control for students' individual characteristics and school composition (see Online Appendix for full results). Variance Inflation Factor (VIF) 


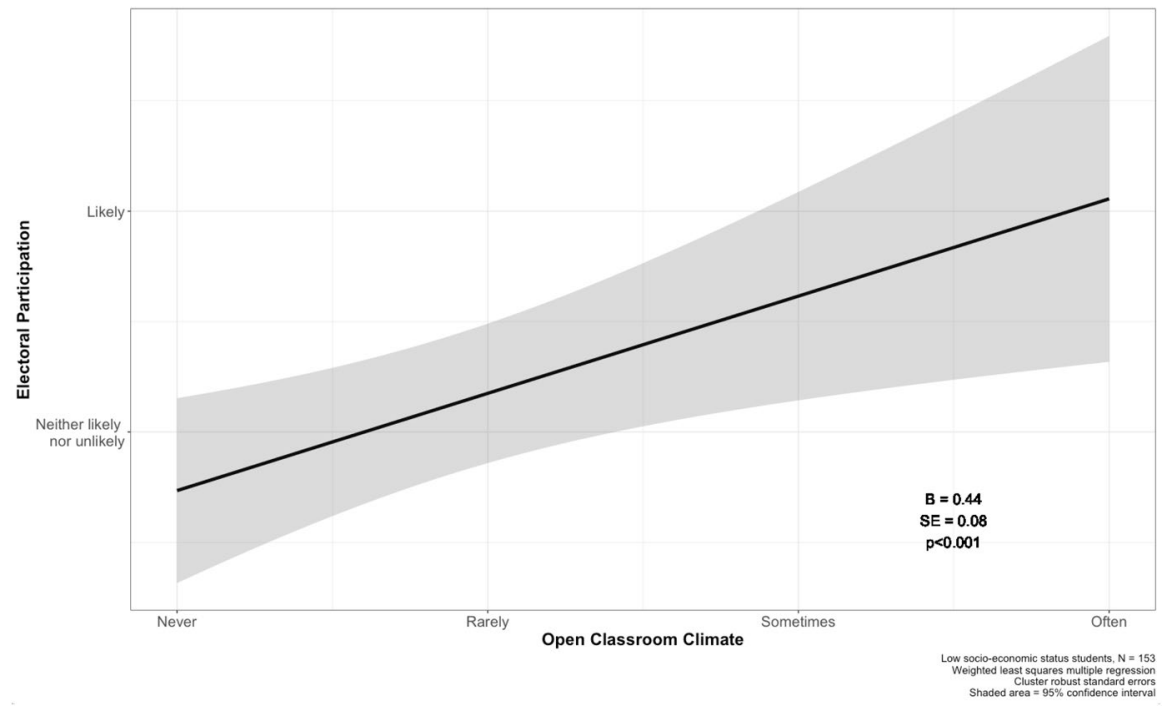

Fig. 7 Predicted effects of open classroom climate on the future electoral participation of students with low socio-economic status (original scales)

scores suggest acceptable levels of collinearity among the predictors used in each model (VIF<3). Focusing first on students' current expressive participation, OCC has a consistent and statistically significant positive effect (e.g. Fig. 6). A single unit increase in OCC results in an average 14\% increase in students' expressive participation. These effects are slightly stronger among low SES students (16\%) and women $(15 \%)$ as compared to high SES students $(11 \%)$ or men $(12 \%)$, and broadly equal between ethnic minority students (14\%) and white students (13\%). Taken together, these results suggest a compensation effect insofar as OCC in school lessons closes the gap in political engagement amongst young people from some under-represented demographic and socio-economic backgrounds (H4 supported).

Political contact also shares statistically significant positive associations with young people's expressive participation. Each one-unit increase in the frequency of political contact results in an $8 \%$ increase in the expressive participation of high SES students and young women, and a $9 \%$ increase among white students. However, the effect seen among low SES students is weaker (5\% rise per one-unit increase in political contact) and no effects are detected among ethnic minority students. These results suggest that political contact may actually have an acceleration effect on students' expressive participation insofar as it stimulates greater engagement amongst traditionally dominant social and demographic groups (H5 unsupported). Whole curricula lessons and participatory activities have no discernible impact on students' expressive participation in the current sample over and above that of OCC and political contact (H2 and $\mathrm{H} 3$ unsupported).

Positive and statistically significant associations are also observed here between OCC and students' anticipated electoral participation. A single unit increase in OCC results in an average $7 \%$ increase in students' voting intentions (e.g. Fig. 7). These 


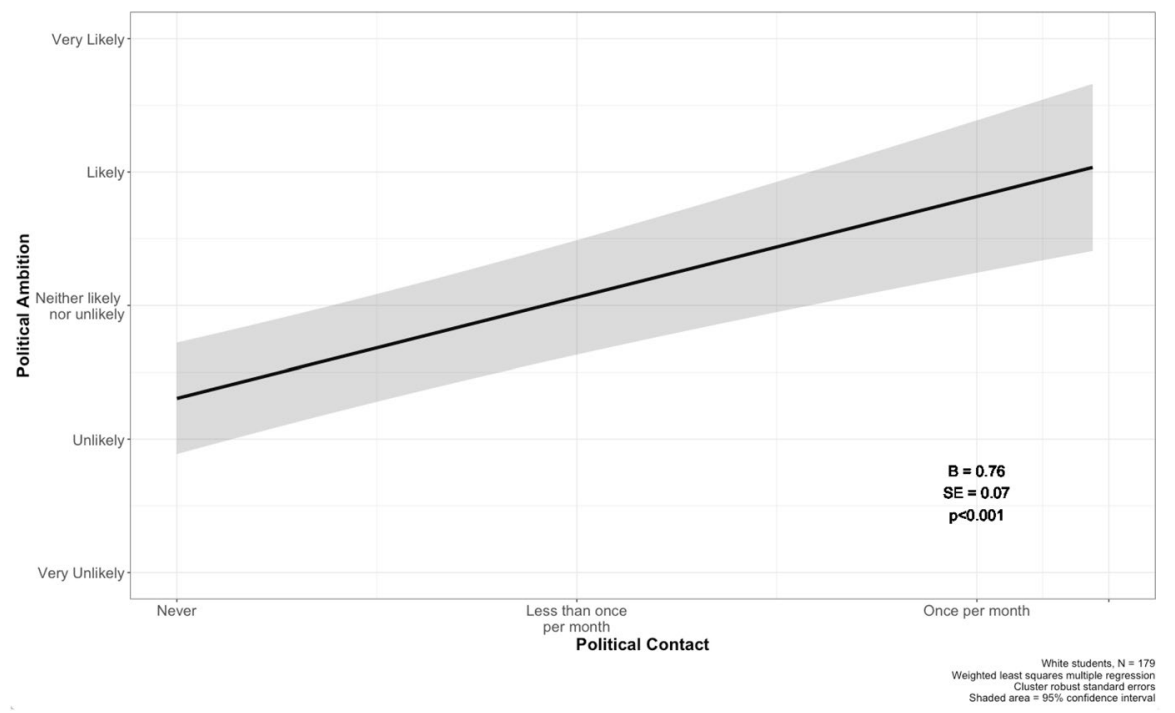

Fig. 8 Predicted effects of political contact on the political ambition of white students (original scales)

effects are also stronger among low SES students (8\%) than high SES students (4\%), which is again indicative of a compensation effect (H4 supported). However, there is no discernible relationship between voting intent and whole curricula lessons $(\mathrm{H} 2$ unsupported), and participatory activities even share a marginal negative association with the voting intentions of some students (H3 unsupported). Political contact appears to share a nuanced relationship with students' voting intentions. On average, each one-unit increase in political contact results in a $4 \%$ decrease in the voting intentions of ethnic minority students (H5 unsupported), but a $4 \%$ increase among young women (H5 supported). However, age is the strongest predictor of voting intent in these models regardless of students' socio-economic status, sex or ethnicity. Students in Key Stage 4 (15-16 years old) are, on average, 13-28\% more likely to anticipate voting in an election than their peers in Key Stage 3 at the start of secondary education (11-12 years old). These findings mirror the aggregate increases in political interest evidenced elsewhere across adolescence and young adulthood (e.g. Neundorf et al. 2013).

The current analysis also reveals a link between civic education in schools and young people's political ambition to stand for elected office. In particular, young people appear to be more likely (or less unlikely) to aspire to political office when they experience political contact in school. On average, each one-unit increase in the frequency of political contact through schooling is associated with a $25 \%$ increase in political ambition. However, these effects once again vary by student characteristics. For example, political contact appears to benefit high SES students more than low SES students, and it has a much stronger effect among white students by comparison to ethnic minority students. Each one-unit increase in political contact correlates with a $38 \%$ rise in political ambition among white students (e.g. Fig. 8), but only $7 \%$ among ethnic minority students. It is possible, therefore, that political contact may 
have an acceleration effect on inequalities in young people's political ambition (H5 unsupported).

All else considered, curricula lessons in politics and citizenship also appear to inhibit the political ambition of ethnic minority and low SES students (H2 unsupported). Each one-unit increase in the frequency of such lessons correlates with a 3\% decrease in political ambition among low SES students and a 5\% decrease among ethnic minority students. This acceleration effect is mirrored by statistically significant positive correlations between OCC and political ambition among high SES and white students that do not reproduce among low SES students or ethnic minority students (H4 unsupported). Once again, participatory activities share an antithetical negative association with the outcome variable (H3 unsupported). It is worth noting that these models explain much lower rates of variance in students' political ambition than either their voting intent or expressive participation (see Online Appendix).

\section{Discussion}

This article adds to a body of comparative research into the role of civic education as a policy response to low levels of political participation amongst young people. At the same time, it advances a smaller but equally important research agenda on the potential compensation effects of civic education upon inequalities in political participation. Focusing on multiple types of civic education in English secondary schools, as well as three different participatory outcomes, this article finds evidence that:

(a) civic education remains a peripheral feature of English schooling, both in terms of formal curricula lessons and extra-curricular or pedagogical practices;

(b) the cumulative quantity of civic education received by students may increase their likely participation in politics through expressive behaviours in the present and their likely turnout in elections or otherwise formal involvement with the electoral system in the future;

(c) an open classroom climate (OCC) that invokes social and political issues in daily learning may drive young people's expressive and electoral participation and close participatory inequalities therein, whilst political contact between students and politicians or political institutions may widen those inequalities; and

(d) civic education appears to contribute to an acceleration of inequalities in young people's political ambition to stand for elected office.

The positive associations found here between OCC and various participatory outcomes echo prior research findings from around the world and, in doing so, affirm the importance of teachers' pedagogic practices in the classroom. Often in contrast to the highly divisive political rhetoric of populist politicians and pundits that young people may encounter online or through the news media, OCC engages students in civil discussion and deliberation about competing viewpoints and 'open questions' (see, in particular, McAvoy and Hess 2013). In doing so, OCC can help students to 
become more informed, more interested and more politically tolerant through deliberative interactions with teachers and peers from quite different social, cultural or political backgrounds (McAvoy et al. 2011; Torney-Purta et al. 2001). These experiences may also, as evidenced here and elsewhere, have a particularly powerful effect on the participatory intentions of young people from under-represented social backgrounds with little or no political socialisation outside of school. ${ }^{2}$

As a previously under-researched form of civic education, it seems that political contact may also be a powerful predictor of young people's political participation. It may, however, accelerate known inequalities in participation. In particular, political contact through schooling shares stronger associations with the expressive participation and political ambition of white students and high-SES students than ethnic minority or low SES students. The findings presented here even suggest that it may stymie the voting intentions of young ethnic minority students. This is a worrying and counter-hypothetical finding that possibly says as much about the descriptive quality of the UK's political class and democratic institutions as it does about the potential impacts of political contact per se. Research on minority empowerment has demonstrated that both a dyadic mapping of descriptive representation between citizen and legislator, as well as collective descriptive representation in legislatures, can increase voter registration, turnout, political interest and efficacy, and informal participation among underrepresented groups (see Uhlaner and Scola 2016). Yet young ethnic minority students in the UK are unlikely to see themselves, or their social and cultural experiences, mirrored in the representatives and representative institutions of UK politics. As of the 2019 General Election, only $10 \%$ of MPs, $4 \%$ of councillors, and $12.7 \%$ of civil servants (including only $6 \%$ of senior civil servants) were from ethnic minority backgrounds (compared to $33 \%$ of students currently in maintained secondary education in England). On one hand, these findings raise interesting questions for future research into the potentially negative or suppressive impact of non-descriptive political contact (with institutions as well as actors) upon minority empowerment among young people. On the other hand, they highlight the possibly beneficial impact of descriptive political contact as a form of civic education.

A similar logic may explain the negative associations found here between curricula citizenship education lessons and the political ambition of young ethnic minority and low SES students. Put simply, it is possible that mainstream political education about non-descriptive political institutions, as well as contact with those institutions, positions a white middle-class relationship to state authority that jars with the precarity and lived experiences of ethnic minority and workingclass young people. This is an argument with a longstanding heritage in debates about formal citizenship education in England. In the late 2000s, the then Labour Government were criticised by teachers and academics alike for using citizenship

\footnotetext{
${ }^{2}$ Given that students are most likely to experience OCC in formal citizenship or civic education lessons, the latter may be considered as a suitable vehicle for the former. It is not surprising, for instance, that the frequency of participants' citizenship education lessons correlated positively with all three participatory outcomes tested in this study (Table 2), but exhibited null effects in the regression models after controlling for OCC (see Online Appendix).
} 
education to promote a compromisingly monocultural view of Britishness (e.g. Osler 2008; Hand and Pearce 2008). Subsequent Coalition and Conservative governments have been similarly criticised for advancing a depoliticised curriculum of personal 'responsibilisation' that focuses more on building social capital than political literacy or active citizenship (e.g. Kisby 2017; Weinberg and Flinders 2018). In contrast to the politics of citizenship education as they've played out in England, Beth Rubin (2007) calls for 'a critical, asset-based approach [to civic education] that is attentive to both community and larger structural and historical context.' This is an important invective that points to a way forward. It is entirely possible that curricula citizenship education and political contact may yet raise the political interests and ambition of all young people, but only once our political institutions and processes (and the courses designed to teach about them) more adequately reflect the social, cultural and ethnic composition and experiences of the whole country.

Whilst the findings presented in this article are informative, a number of omitted variables may yet improve our academic understanding of this topic. The negative association found between participatory activities (such as voting for a school council) and participatory outcomes is, for instance, a theoretically anomalous result that could be confounded by variables that were neither considered nor measured in this study. Future research may seek to develop a more sophisticated understanding of this result and the broader political impact of civic education by incorporating known by-products such as political knowledge and democratic attitudes (e.g. Schulz et al. 2016, p. 193; Barrett 2020). It is entirely possible that types and styles of civic education do not positively impact participatory outcomes because young people receive them per se, but because they foremost develop students' knowledge (i.e. about when and how to participate) and democratic orientation (i.e. why to participate) where they are done well. Future studies should seek to test these assumptions with larger samples of longitudinal or experimental observations, as well as controlled trials, that allow for appropriate causal mediation analyses and control for the quality of civic education teaching in schools.

The importance of the findings presented in this article depends, in large part, upon their significance for those with the power to alter educational provision. For policy-makers and politicians in England, this means (a) committing to provide every child with a minimum offer of civic education in school by, in the first instance, resourcing and monitoring existing statutory requirements to teach citizenship education lessons, (b) resourcing effective provision by funding initial teacher training (ITT) and continued professional development (CPD) opportunities (principally related to $\mathrm{OCC}$ ), (c) facilitating regular and concerted descriptive political contact between elected or non-elected political actors and school students of all ages, and (d) thinking seriously about the content and inclusivity of existing curricula.

Supplementary Information The online version contains supplementary material available at https://doi. org/10.1057/s41293-021-00186-4.

\section{Declarations}

Conflict of Interest: This research was funded by the Joseph Rowntree Reform Trust (Ref. 190903).

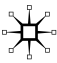




\section{References}

Barrett, M. (2020). The council of Europe's reference framework of competences for democratic culture: Policy context, content and impact. London Review of Education, 8(1), 1-17.

Bird, K., T. Saalfeld, and A. Wust. 2010. The Political Representation of Immigrants and Minorities: Voters, Parties and Parliaments in Liberal Democracies. London: Routledge.

Burns, N., K.L. Schlozman, and S. Verba. 2001. The Private Roots of Public Action. Cambridge: Harvard University Press.

Campbell, D.E. 2006. Why We Vote: How Schools and Communities Shape Our Civic Life. Princeton, NJ: Princeton University Press.

Campbell, D.E. 2008. Voice in the Classroom: How an Open Classroom Climate Fosters Political Engagement Among Adolescents. Political Behaviour 30 (4): 437-454.

Campbell, D.E., and R.G. Niemi. 2015. Testing Civics: State-Level Civic Education Requirements and Political Knowledge. American Political Science Review 110 (3): 495-511.

Castillo, J.C., D. Miranda, M. Bonhomme, C. Cox, and M. Bascopé. 2015. Mitigating the Political Participation Gap from the School: The Roles of Civic Knowledge and Classroom Climate. Journal of Youth Studies 18 (1): 16-35.

Clay, K.L., and B. Rubin. 2020. "I Look Deep Into This Stuff Because It's a Part of Me": Toward a Critically Relevant Civics Education. Theory \& Research in Social Education 48 (2): 161-181.

Dahl, R. 1989. Democracy and lts Critics. New Haven CT: Yale University Press.

Dalton, R.J. 2017. The Participation Gap: Social Status and Political Inequality. Oxford: Oxford University Press.

Davies, I., M. Evans, M. Fülöp, D. Kiwan, A. Peterson, and J.B.-Y. Sim, eds. 2019. Taking Action for Change: Educating for Youth Civic Engagement and Activism. York: University of York, Department of Education.

Deimel, D., Hoskins, B., and Abs, H.J. (2020). How do schools affect inequalities in political participation: compensation of social disadvantage or provision of differential access? Educational Psychology, 40(2): 146-166.

DelliCarpini, M.X., and S. Keeter. 1996. What Americans Know About Politics and Why It Matters. New Haven: Yale University Press.

Department for Education (DfE). 2013. The National Curriculum in England: Framework Document. London: DfE.

Department for Education (DfE). 2019. Schools, Pupils and Their Characteristics: January 2019. https:// www.gov.uk/government/statisticsischools-pupils-andtheir-characteristics-january-2019. accessed 05 June 2020.

Department for Education (DfE). 2020. Statistics on the Size and Characteristics of the Schools' Workforce in State-Funded Schools. https://www.gov.uk/government/collections/statistics-school-workf orce accessed 04 January 2021.

Donbavand, S., and B. Hoskins. 2021. Citizenship Education for Political Engagement: A Systematic Review of Controlled Trials. Social Sciences 10 (151): 1-19.

Garcia-Cabrero, B., A. Sandoval-Hernandez, E. Treviño-Villarreal, S. Diazgranados-Ferrans, and M. Perez-Martinez, eds. 2017. Civics and Citizenship. Theoretical Models and Experiences in Latin America. Rotterdam: Sense Publishers.

Hand, M., and J. Pearce. 2008. Should Patriotism be Promoted, Tolerated or Discouraged in British Schools? Final Project Report. London: IOE.

Heath, A., S. Fisher, G. Rosenblatt, D. Sanders, and M. Sobolewska. 2013. The Political Integration of Ethnic Minorities in Britain. Oxford: Oxford University Press.

Hooghe, M., and R. Dassonneville. 2013. Voters and Candidates of the Future: The Intention of Electoral Participation Among Adolescents in 22 European Countries. Young 21 (1): 1-28.

Hoskins, B., J.G. Janmaat, and G. Melis. 2017. Tackling Inequalities in Political Socialisation: A Systematic Analysis of Access to and Mitigation Effects of Learning Citizenship at School. Social Science Research 68: 88-101.

Keating, A., D. Kerr, T. Benton, E. Mundy, and J. Lopes. 2010. Citizenship Education in England 20012010: Young People's Practices and Prospects for the Future. The Eighth and Final Report from the Citizenship Education Longitudinal Study (CELS) Research Report DFE- RR059. London: Department for Education. 
Keating, A., and J.G. Janmaat. 2016. Education Through Citizenship at School: Do School Activities Have a Lasting Impact on Youth Political Engagement? Parliamentary Affairs 69: 409-429.

Kennedy, K.I. 2012. Asian Students' Citizenship Values and Their Relationship to Civic Understanding: An Exploratory Study Comparing Thai and Hong Kong Students. Research in Comparative and International Education 7 (2): 248-259.

Kisby, B. 2017. 'Politics Is Ethics Done in Public': Exploring Linkages and Disjunctions between Citizenship Education and Character Education in England. Journal of Social Science Education 16 (3): 7-20.

Kleinnijenhuis, J., M. Maurer, H.M. Kepplinger, and D. Oegema. 2001. Issues and Personalities in German and Dutch Television News: Patterns and Effects. European Journal of Communication 16 (3): 337-359.

Knowles, R.T., and J. McCafferty-Wright. 2015. Connecting an Open Classroom Climate to Social Movement Citizenship: A Study Using the International Civic and Citizenship Study Among 8th Graders in Western Europe. Journal of Social Studies Research 39 (4): 255-269.

Knowles, R.T., J. Torney-Purta, and C. Barber. 2018. Enhancing Citizenship Learning with International Comparative Research: Analyses of IEA Civic Education Datasets. Citizenship Teaching \& Learning 13 (1): 7-30.

Levinson, M. 2013. Education as a Civic Right: Using Schools to Challenge the Civic Empowerment Gap. Poverty \& Race 22(3): 1-6

Marien, S., and M. Hooghe. 2010. Inequalities in Non-institutionalised Forms of Political Participation: A Multi-level Analysis of 25 Countries. Political Studies 58: 187-213.

Martens, A.M., and J. Gainous. 2013. Civic Education and Democratic Capacity: How Do Teachers Teach and What Works? Social Science Quarterly 94 (4): 956-976.

McAvoy, P., Hess, D., and Kawashima-Ginsberg, K. 2011. How do students experience and learn from high quality discussions of political issues? Paper presented at the annual meeting of the American Educational Research Association, New Orleans, LA.

McAvoy, P., and D. Hess. 2013. Classroom Deliberation in an Era of Political Polarisation. Curriculum Inquiry 43 (1): 14-47.

Neundorf, A., K. Smets, and G.M. Garcia Albacete. 2013. Homemade Citizens: The Development of Political Interest During Adolescence and Young Adulthood. Acta Politica 48 (1): 92-116.

Neundorf, A., R.G. Niemi, and K. Smets. 2016. The Compensation Effect of Civic Education on Political Engagement: How Civics Classes Make Up for Missing Parental Socialization. Political Behaviour 38 (4): 921-949.

Neundorf A., and K. Smets. 2017. Political socialization and the making of citizens. Oxford Handbooks Online. https://www.oxfordhandbooks.com/view/ https://doi.org/10.1093/oxfordhn/9780199935 307.001.0001/oxfordhn-9780199935307-e-98. accessed 25 May 2020

OECD. 2017. How's Life? 2017: Measuring Well-Being. Paris: OECD publishing.

Osler, A. 2008. Citizenship Education and the Ajegbo Report: Re-imagining a Cosmopolitan Nation. London Review of Education 6 (1): 11-25.

Persson, M. 2015. Classroom Climate and Political Learning: Findings from a Swedish Panel Study and Comparative Data. Political Psychology 36 (5): 587-601.

Plutzer, E. 2018. Demographics and the Social Bases of Voter Turnout. In The Routledge Handbook of Elections, Voting Behaviour and Public Opinion, ed. J. Fisher, E. Fieldhouse, M.N. Franklin, R. Gibson, M. Cantijoch, and C. Wlezein, 69-82. Abingdon: Routledge.

Quintelier, E., and M. Hooghe. 2013. The Relationship Between Political Participation Intentions of Adolescents and a Participatory Democratic Climate at School in 35 Countries. Oxford Review of Education 39 (5): 567-589.

Rubin, B. C. 2007. "There's still not justice": Youth civic identity development amid distinct school and community contexts. Teachers College Record, 109, 449-481.

Schulz, W., J. Ainley, J. Fraillon, B. Losito, G. Agrusti, and T. Friedman. 2016. Becoming Citizens in a Changing World: IEA International Civic and Citizenship Education Study 2016 International Report. Amsterdam: Springer Open.

Soo, N., J. Weinberg, and K. Dommett. 2020. One Moment, Please: Can the Speed and Quality of Political Contact Affect Democratic Health. British Journal of Politics and International Relations. https://doi.org/10.1177/1369148120919683.

Sloam, J., and M. Henn. 2018. Youthquake 2017: The Rise of Young Cosmopolitans in Britain. London: Palgrave. 
Sloam, J., B. Kisby, M. Henn, and B. Oldfield. 2021. Voice, Equality and Education: The Role of Higher Education in Defining the Political Participation of Young Europeans. Comparative European Politics 19: 296-322.

Tedesco, J.C. 2006. Web Interactivity and Young Adult Political Efficacy. In The Internet Election: Perspectives on the Web in Campaign 2004, ed. A.P. Williams and J.C. Tedesco, 187-202. Lanham, MD: Rowman \& Littlefield.

Teorell, J., P. Sum, and M. Tobiasen. 2007. Participation and Political Equality: An Assessment of LargeScale Democracy. In Citizenship and Involvement in European Democracies: A Comparative Analysis, ed. J.W. van Deth, J.R. Montero, and A. Westholm, 384-414. New York: Routledge.

Tonge, J., A. Mycock, and B. Jeffery. 2012. Does Citizenship Education Make Young People BetterEngaged Citizens? Political Studies 60: 578-602.

Torney-Purta, J., and C. Barber. 2005. Democratic School Engagement and Civic Participation Among European Adolescents: Analysis of Data from the IEA Civic Education Study. Journal of Social Science Education 4 (3): 13-27.

Torney-Purta, J., Lehmann, R., Oswald, H., Schulz, W. (2001). Citizenship and education in twenty-eight countries: Civic knowledge and engagement at age fourteen. Amsterdam, the Netherlands: International Association for the Evaluation of Educational Achievement.

Trevino, C., C. Bejares, C. Villalobos, and E. Naranjo. 2016. Influence of Teachers and Schools on Students' Civic Outcomes in Latin America. Journal of Educational Research 110 (6): 604-618.

Uhlaner, C.J., and B. Scola. 2016. Collective Representation as a Mobilizer: Race/Ethnicity, Gender, and Their Intersections at the State Level. State PolitIcs \& Policy Quarterly 16 (2): 227-263.

UK Government. 2021. Entry rates into higher education. https://www.ethnicity-facts-figures.service.gov. uk/education-skills-and-training/higher-education/entry-rates-into-higher-education/latest. Accessed 08 June 2021.

Warren, M. 2002. What Can Democratic Participation Mean Today? Political Theory 30 (5): 677-701.

Weinberg, J., and M. Flinders. 2018. Learning for Democracy: The Practice and Politics of Citizenship Education in the United Kingdom. British Educational Research Journal 44 (4): 573-592.

Weinberg, J. 2019. Who's Listening to whom? The UK House of Lords and Evidence-Based PolicyMaking on Citizenship Education. Journal of Education Policy, https://doi.org/10.1080/02680939. 2019.1648877.

Whiteley, P. 2014. Does Citizenship Education Work? Evidence from a Decade of Citizenship Education in Secondary Schools in England. Parliamentary Affairs 67: 513-535.

Wolbrecht, C., and D.E. Campbell. 2007. Leading by Example: Female Members of Parliament as Political Role Models. American Journal of Political Science 51 (October): 921-939.

Zhang, T., J. Torney-Purta, and C. Barber. 2012. Students' Conceptual Knowledge and Process Skills in Civic Education: Identifying Cognitive Profiles and Classroom Correlates. Theory \& Research in Social Education 40 (1): 1-34.

Publisher's Note Springer Nature remains neutral with regard to jurisdictional claims in published maps and institutional affiliations. 